Розділ І. Ціннісні орієнтири духовно-інтелектуального виховання, розвиток духовно-інтелектуальних якостей особистості в умовах співпраці й інклюзії

\title{
ІНТЕЛЕКТУАЛЬНИЙ ТА ДУХОВНИЙ РОЗВИТОК МАЙБУТНЬОГО МЕНЕДЖЕРА ОСВІТИ
}

\author{
Мармаза О. I. \\ кандидат педагогічних наук, професор, професор кафедри наукових основ \\ управління, Харківський національний педагогічний університет \\ імені Г. С. Сковороди, м. Харків, Україна
}

У статті актуалізовано проблему професійної підготовки менеджерів освіти; здійснено аналіз особливостей управлінської діяльності керівника закладу освіти на сучасному етапі розвитку суспільства і освіти; визначено головні вимоги до професіоналізму керівника закладу освіти, його інтелектуального та духовного розвитку.

Ключові слова: управління, керівник закладу освіти, менеджер освіти, професійна підготовка.

The article actualizes the problem of professional training of managers of education; the analysis of features of administrative activity of the head of educational institution at the present stage of development of a society and education is carried out; the main requirements to the professionalism of the head of educational institution, their intellectual and spiritual development are defined.

Key words: management, head of educational institution, manager of education, professional training.

Підгрунтям продуктивної діяльності та успішності менеджера освіти є його підготовка до професії. Професія — це вид праці людини, яка володіє спеціальним комплексом теоретичних знань, практичних умінь, моральних якостей, яких вона набула у результаті спеціальної підготовки та досвіду роботи. Від професійних дій керівника залежить конкурентоздатність закладу освіти та життєдіяльність інших співробітників.

Професійна підготовка менеджерів освіти в Україні здійснюється з 2002 року, коли було відкрито спеціальність «Управління навчальним закладом», яка передбачала спеціальну фахову підготовку керівників закладів освіти різних типів та форм власності. Проте ми можемо констатувати той факт, що у наш час до управління закладами освіти iз високопрофесійними педагогічними колективами та покладеними на них суспільством стратегічними завданнями все ще долучаються люди без спеціальної підготовки. 
Вважаємо, за доцільне актуалізувати проблему професійної підготовки менеджерів освіти на основі аналізу особливостей управлінської діяльності та вимог до керівника на даному етапі розвитку суспільства і освіти.

Концепція «Нова українська школа» [1] може бути реалізована тільки за наявності потужного менеджерського корпусу, що складається із професіоналів із сформованими лідерськими якостями, розвинутим інтелектом, моральними чеснотами. Зазначене передбачає професійну підготовку компетентних менеджерів освіти, формування управлінців нової генерації, здатних мислити і діяти системно, у тому числі у кризових ситуаціях. Доцільно виокремити суттєві ознаки управлінського мислення керівника перехідного періоду на зламі століть: спрямованість на людину, збільшення уваги до соціальних потреб персоналу, гуманізація, сформованість системи цінностей, духовність.

У Стандарті вищої освіти другого (магістерського) рівня галузі знань 07 «Управління та адміністрування» спеціальності 073 «Менеджмент» визначено компетентності магістра 3 менеджменту, серед яких такі, як: уміння обирати та використовувати концепції, методи та інструментарій менеджменту, у тому числі у відповідності до міжнародних стандартів; установлювати критерії, за якими організація визначає подальший напрям розвитку; розробляти і реалізовувати відповідні стратегії та плани; здатність до ефективного використання та розвитку людських ресурсів в організації; вміння створювати та організовувати ефективні комунікації в процесі управління; здатність використовувати психологічні технології роботи з персоналом; навички формування та демонстрації лідерських якостей; виявляти ініціативу та підприємливість; уміння планувати і проводити наукові дослідження, готувати результати наукових робіт до оприлюднення; уміти управляти організацією, ії змінами, здійснюючи їх інформаційне, методичне, матеріальне, фінансове та кадрове забезпечення, в тому числі у відповідності до міжнародних стандартів та рекомендацій моделей досконалості; моделювати об' єкти і процеси у сфері менеджменту, застосовуючи математичні методи та інформаційні технології; ідентифікувати та класифікувати відомі і виявляти нові об'єкти в сфері менеджменту, описувати властивості, явища та процеси, їм притаманні [3]. Навчання за даною спеціальністю дозволило б прийти до закладу освіти керівнику із сформованим професійним базисом та розвиненим інтелектом. 
Розділ І. Ціннісні орієнтири духовно-інтелектуального виховання, розвиток духовно-інтелектуальних якостей особистості в умовах співпраці й інклюзії

Нажаль, здебільше новопризначені керівники закладів освіти не мають відповідної професійної підготовки до управління. Як правило, вони є висококваліфікованими фахівцями із різних педагогічних спеціальностей. Відтак підгрунтя проблеми невідповідності реального рівня компетентності керівників закладів освіти необхідному для ефективного управління криється саме у відсутності менеджерської освіти.

Зазначимо, що управлінська компетентність керівника - це система знань та умінь, що є адекватними структурі та змісту його професійної діяльності. Наполягаємо, що ця система має суттєві відмінності від гносеологічного ряду педагога.

Розглядаючи структуру і зміст моделі професійної компетентності керівника закладу освіти, ми виокремили дві підсистеми знань, які необхідні для іiі побудови. Вкрай важливо, щоб знання не являли собою добірку абстрактних понятійних елементів, а відбивали діалектику пізнання (від загального до конкретного і навпаки) з урахуванням їх місця у пізнавальному процесі, а також сутнісних особливостей кожного типу знань [2].

Першу складають такі групи: соціально-правові, фінансово-економічні, педагогічні, управлінські, психологічні знання. Такі групи знань виокремлено, зважаючи на те, що: основний вид діяльності керівника закладу освіти — управлінський, що обумовлює необхідність досконалого знання теорії та практики управління; керівник управляє соціальною системою, тобто системою, яка об'єднує людей, а відтак він повинен знати основи психології та психології менеджменту; об’єкт управлінської діяльності керівника - заклад освіти обумовлює необхідність оволодіння педагогічними знаннями та уміннями; керівник закладу освіти може здійснювати управління тільки на підставі глибокої обізнаності у соціально-правовій сфері; керівник закладу освіти забезпечує його функціонування та розвиток, виходячи із знання основних механізмів господарювання та фінансово-економічних знань.

Друга підсистема — це гносеологічний ряд: методологічні знання (закони, закономірності ідеї, теорії); нормативні знання (принципи, правила, нормативи, інструкції, положення); змістовні знання (категоpiii, основні поняття, факти, явища, процеси); знання способу діяльності (методи, способи, прийоми, операції) та уміння. 
У представленій парадигмі знання замикаються на методиках, тобто на знаннях способу дії, які безпосередньо виходять на професійні уміння. Таким чином, на основі знань формуються управлінські уміння. За цільовими ознаками їх можна згрупувати у діагностико-прогностичні, організаційно-регулятивні, контрольно-коригуючі. У поєднанні зі специфікою діяльності керівника дана класифікація набуває предметний управлінський зміст.

Системоутворювальними якостями майбутнього менеджера освіти є:

а) духовність та моральність - це уміння, співпереживати, чути голос совісті, відповідальність, чесність, справедливість, вимогливість до себе та інших, витримка, тактовність, доброзичливість, повага до людей, сила волі, почуття гумору, демократичність;

б) інтелект: розвинені мислення, пам'ять, уявлення. Культурна освіченість керівника полягає у постійній потребі дізнаватись про досягнення, творчість людства. Антропологічні знання - це система гуманітарних, природничих, політекономічних, психологічних, художніх та інших знань, які сприяють пізнанню людини. Вони є основою для евристичної діяльності керівника, формування його ділової поведінки, зумовлюють морально-психологічний стан.

Отже, попри наявний науковий доробок учених та практичний досвід 3 підготовки менеджерів освіти, проблема підвищення управлінської компетентності керівника, як домінантної складової модернізації загальної середньої освіти, інтелектуального та духовного розвитку залишається актуальною та важливою для подальших наукових розвідок, педагогічних та суспільних дискусій.

\section{Список використаних джерел:}

1. Концепція «Нова українська школа». URL: https://www.kmu.gov.ua / storage/app/media/reforms/ukrainska-shkola-compressed.pdf (дата звернення: 04.02.2020).

2. Мармаза О. І. Менеджмент освітніх організацій. Харків, 2017. 126 с.

3. Стандарт вищої освіти другого (магістерського) рівня галузі знань 07 «Управління та адміністрування» спеціальності 073 «Менеджмент». Київ, 2019. URL: https://mon.gov.ua/storage/app/media/vishcha-osvita (дата звернення: 20.01.2020). 